\title{
Genetic analysis of the population structure of socially organized oystercatchers (Haematopus ostralegus) using microsatellites
}

\author{
R. VAN TREUREN, ${ }^{*}+\neq$ R. BIJLSMA, ${ }^{*}$ J. M. TINBERGEN, † D. HEG† and L. VAN DE ZANDE* \\ *Department of Genetics, University of Groningen, Kerklaan 30, 9751 NN Haren, The Netherlands, +Zoological Laboratory, \\ University of Groningen, Kerklaan 30, 9751 NN Haren, The Netherlands
}

\begin{abstract}
On the island of Schiermonnikoog (The Netherlands), the breeding population of oystercatchers can be divided into two groups: 'residents' and 'leapfrogs', based on their distinct social characteristics and limited probabilities of status change between breeding seasons. In order to investigate whether this social organization has caused local genetic differentiation, leapfrogs and residents were compared at eight polymorphic microsatellite loci. No significant genetic subdivision between residents and leapfrogs was observed $(\Theta=0.0000 ; 95 \%$ confidence interval $(\mathrm{CI}),-0.0027-0.0033)$, indicating that the oystercatcher population on the island of Schiermonnikoog has to be considered as one panmictic unit. Investigation of three additional locations in the northern part of The Netherlands did not reveal significant genetic population subdivision either $(\Theta=-0.0005 ; 95 \%$ CI, - 0.0045-0.0037), despite the fact that adult oystercatchers show extreme fidelity to their breeding localities. These results indicate panmixis and considerable levels of gene flow within the northern part of The Netherlands. Thus, the results from genetical analyses do not seem to be in agreement with observational data on the dispersal behaviour of breeding individuals. It is argued that the lack of population structure, locally on Schiermonnikoog as well as across larger geographical distances, is to be attributed to high levels of gene flow through dispersal of juvenile birds.
\end{abstract}

Keywords: gene flow, genetic differentiation, Haematopus ostralegus, microsatellites, population structure, social organization

Received 15 June 1998; revision received 22 September 1998; accepted 22 September 1998

\section{Introduction}

Despite their flying ability, substantial genetic differentiation of avian populations can occur, particularly if gene flow is limited due to the social system of the species (Triggs et al. 1992). Oystercatchers (Haematopus ostralegus) compete for both breeding and foraging territories. Based on their social status, breeding birds on the saltmarsh of the island of Schiermonnikoog, The Netherlands, have been divided into two distinct groups (Ens et al. 1992): (i) 'residents', that occupy breeding territories adjacent to their foraging territories on the mudflats; and (ii)

Correspondence: R. Van Treuren. Fax: + 31 317418094; E-mail: r.vantreuren@cpro.dlo.nl

$\ddagger$ Present address: Centre for Genetic Resources, The Netherlands, DLO-Centre for Plant Breeding and Reproduction Research, PO Box 16, 6700 AA Wageningen, The Netherlands. 'leapfrogs', that have their breeding territories more inland behind the resident breeding territories and have their foraging territories further away on the mudflats behind the resident foraging territories. Resident territories are considered to be of higher quality because breeders can take their chicks to the adjacent feeding places, whereas leapfrogs have to transport food from the foraging areas to their chicks. As a result the reproductive success of residents, measured by the annual number of chicks fledged, is on average about 3.5-times higher than for leapfrogs (Ens et al. 1992). Occasional transitions of breeding birds between social groups have been observed (Ens et al. 1995). The social status of these birds at birth, however, is unknown. As social status might have changed at recruitment, switching breeders may be individuals returning to their social status at birth. Therefore, the level of gene flow between residents and leapfrogs cannot simply be derived 
from these demographic data. In the present study we examine the level of genetic differentiation between residents and leapfrogs in order to decide whether these two social groups are one panmictic population.

Genetic differentiation may also be observed when geographically separated populations are compared, as has been recently reported for nine shorebird species (Haig et al. 1997). In The Netherlands, the oystercatcher is a common breeder that can be found in large numbers along the coast and on the Wadden islands in the northern part of the country. Overwintering takes place in the breeding areas, except during severe conditions when southward migration occurs. Breeders nearly always return to the same breeding localities in the next season (Harris et al. 1987; Ens et al. 1993). This strong breeding-site fidelity may have promoted genetic differentiation among geographically subdivided populations. In order to investigate genetic divergence across larger distances and to obtain a reference for our findings on Schiermonnikoog, we also sampled oystercatchers from geographically separated breeding localities within the northern part of The Netherlands.

Because of the high level of polymorphism and the relative ease of use and interpretation, microsatellites are considered ideal for a wide variety of applications in population genetic research (Queller et al. 1993). In the present study we use microsatellites to determine whether residents and leapfrogs from Schiermonnikoog constitute two genetically differentiated populations, and relate this to differentiation observed among geographically separated populations.

\section{Materials and methods}

\section{Population sampling}

During 1994-96 blood samples were taken from oystercatchers at four different locations (Fig. 1). A total of 94 residents and 135 leapfrogs was sampled from Schiermonnikoog; about 50 individuals were sampled from other locations. The approximate population sizes were estimated to be 2400 breeding pairs on the isle of Schiermonnikoog (Ens 1992), 300 in Holwerd (Wadvogelwerkgroep FFF: K. Koopman, personal communication), 300-500 on the isle of Griend (A. Brenninkmeijer \& E. Stienen, personal communication) and 3500 on the isle of Texel (Dijksen 1996). To ensure that only breeding birds were sampled, individuals were caught on their nest during the reproductive stage (March-August). To prevent sampling of the same birds during different visits, ring numbers were recorded and uncoded individuals were supplied with rings. About $200-500 \mu \mathrm{L}$ of blood was taken from the leg vein and stored in $1.5 \mathrm{~mL}$ autoclaved Eppendorf tubes containing $500 \mu \mathrm{L}$ of $20 \%$ DMSO, $4 \mathrm{M} \mathrm{NaCl}$. Tubes were kept at $-20^{\circ} \mathrm{C}$ upon return to the laboratory.

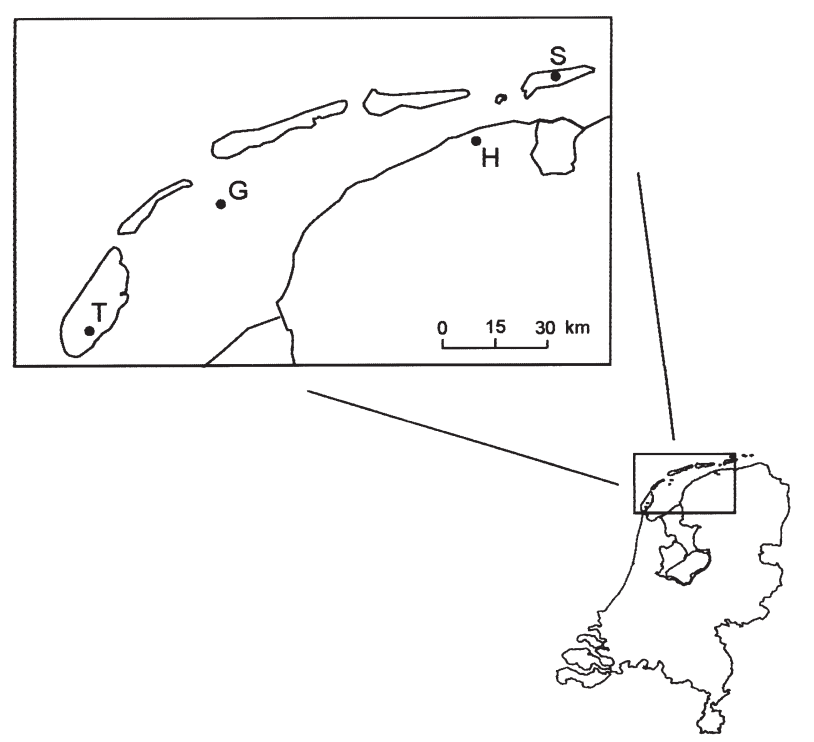

Fig. 1 Location of the four oystercatcher populations in The Netherlands: Schiermonnikoog (S), Holwerd (H), Griend (G) and Texel (T).

\section{DNA extractions}

To extract DNA from the samples, $1 \mathrm{~mL}$ of digestion buffer (100 mM NaCl, $10 \mathrm{~mm}$ Tris pH 8.0, 25 mm EDTA $\mathrm{pH}$ 8.0, 0.5\% SDS, $0.1 \mathrm{mg} / \mathrm{mL}$ proteinase $\mathrm{K}$ ) was added to $100 \mu \mathrm{L}$ of blood and incubated overnight at $55^{\circ} \mathrm{C}$. The following day, $10 \mu \mathrm{L}$ of proteinase $\mathrm{K}(10 \mathrm{mg} / \mathrm{mL})$ was added again, followed by $1 \mathrm{~h}$ of incubation. DNA was then purified by a number (depending on the clarity of the water phase) of phenol-chloroform extractions, followed by ethanol precipitation. The DNA was dissolved in $500 \mu \mathrm{L}$ of $10 \mathrm{~mm}$ Tris, $1 \mathrm{~mm}$ EDTA and stored at $4{ }^{\circ} \mathrm{C}$. The DNA concentration of the samples was determined by spectrophotometry.

\section{Microsatellite cloning}

A mixture of DNA from four individual oystercatchers was digested to completion with restriction enzyme $\mathrm{MboI}$. After electrophoresis on a 1\% agarose gel, the 200-1000 bp size fraction was isolated by electroelution and ligated into the BamHI site of the dephosphorylated plasmid vector pBluescript SK+. The ligation products were used to transform competent Escherichia coli XL1-Blue, followed by recombinant screening using selective agar plates containing X-Gal, IPTG and ampicillin. The resulting genomic library consisting of 5524 bacterial clones was screened for dinucleotide repeat motifs using synthetic oligonucleotides $(\mathrm{GT})_{7}$ and $(\mathrm{GA})_{7}$ endlabelled with ${ }^{32} \mathrm{P}$. A total of 42 positive clones $\left(7.6 \times 10^{-3}\right)$ was identified and sequenced, revealing 33 microsatellites including 17 perfect $(\mathrm{GT})_{n}$ repeats, 11 
imperfect $(\mathrm{GT})_{n}$ repeats, two imperfect $(\mathrm{GA})_{7}$ repeats and three additional $T_{n}$ repeats. For nine of the positive clones either no repeat motifs could be found, or no primer sets could be designed due to the close location of the microsatellite locus to the cloning site, or inserts appeared to be identical to those of other positives. Four out of the 33 primer sets failed to amplify the microsatellite after optimization of PCR conditions.

\section{Microsatellite analysis}

PCR reactions were carried out in $10 \mu \mathrm{L}$ volumes, containing $100 \mathrm{ng}$ of template DNA, $0.5 \mu \mathrm{M}$ each primer, $0.2 \mathrm{mM}$ dATP, dGTP and dTTP, $0.02 \mathrm{~mm} \mathrm{dCTP,} 1 \times$ Taq polymerase buffer, 0.4 units of Taq polymerase (Pharmacia) and $0.14 \mu \mathrm{Ci}$ $\left[\alpha^{32} \mathrm{P}\right]$-dCTP $(3000 \mathrm{Ci} / \mathrm{mmol})$. The following thermal profile was used to amplify microsatellites: $3 \mathrm{~min}$ at $94^{\circ} \mathrm{C} ; 30$ cycles of $1 \mathrm{~min}$ at $94^{\circ} \mathrm{C}, 2 \mathrm{~min}$ at $T_{m}$ (optimal annealing temperature) and $1.5 \mathrm{~min}$ at $72{ }^{\circ} \mathrm{C}$; followed by $10 \mathrm{~min}$ at $72{ }^{\circ} \mathrm{C}$. Labelled PCR products were separated on 5\% denaturing polyacrylamide (Biozym, Sequagel XR) gels and exposed to medical X-ray film (Fuji). In each PCR a sequence ladder of the plasmid vector pBluescript SK+ was used as a size standard, together with a positive (PCR reaction of $2 \mathrm{ng}$ of plasmid DNA containing the microsatellite) and negative (PCR reaction without template DNA) control.

Each microsatellite was tested for polymorphism by analysing a total number of 20 DNA samples from three different populations. If no variation was detected, the locus was considered monomorphic and not investigated further.

\section{Data analysis}

For each (sub)population, deviations from HardyWeinberg expectations were analysed using an exact test on pooled genotypes (Haldane 1954). All pairwise combinations of loci were tested for significant deviations from linkage equilibria (Hedrick et al. 1978). When more than two alleles were present, data were collapsed into multiple allelic classes, although this may decrease the power of the test (Weir \& Cockerham 1978).

To avoid bias in estimates of the level of genetic differentiation, equal sample sizes were used by taking random samples from (sub)populations with a surplus of analysed individuals. Variance estimates for F-statistics (Weir \& Cockerham 1984) were obtained by jackknifing over loci and confidence intervals were generated by bootstrapping over loci (1000 replications). Estimates of genetic differentiation $(\Theta)$ were tested for significant deviations from zero using the chi-square test of heterogeneity of gene frequencies (Workman \& Niswander 1970). Pairwise comparisons of (sub)populations were made by calculating Nei's (1972) genetic distances and by chisquare testing of allele frequency differences (Nei 1987).
All analyses, except for testing linkage disequilibria, were carried out by using the computer program TFPGA (version 1.3, March 1998, M. P. Miller, unpublished). The sequential Bonferroni technique was applied when single tests analysed simultaneously yielded significant results (e.g. Rice 1989). In this procedure simultaneous tests for different loci were treated as replicate observations within a (sub)population.

\section{Results}

\section{Microsatellite polymorphism}

Of the 29 microsatellites that amplified successfully, five showed unclear banding patterns. Of the remaining microsatellites, $16(67 \%)$ appeared monomorphic, and only eight $(33 \%)$ polymorphic (Table 1$)$. For these polymorphic loci, a moderate level of allelic diversity was observed (2-6 alleles per locus; Table 2). For all loci, the size differences of the alleles corresponded to additions or deletions of repeat units. No significant deviations between observed and expected genotype numbers were found in any of the (sub)populations (results not shown), except for locus $20 H 7$. For this locus, a significant heterozygote deficit was observed that was consistent across populations (Table 2) and can be accounted for by the presence of a null allele (Van Treuren 1998). For this reason locus $20 H 7$ was omitted from further analyses. Microsatellite loci were in linkage equilibrium in each population.

\section{Population differentiation}

Comparison of genetic variation showed only few qualitative differences among (sub)populations. Population Griend lacked allele 111 for locus 16D10, and alleles 141 and 147 for locus $20 \mathrm{H} 7$ were only found in leapfrogs on the island of Schiermonnikoog. These cases all concerned rare alleles (Table 2). In general, allele frequency differences were small among (sub)populations. No significant level of genetic differentiation was found between leapfrogs and residents on the island of Schiermonnikoog (Table 3a), for any locus. The overall $\Theta$-value was estimated to be 0.0000 (95\% CI, -0.0027-0.0033), indicating that the population of oystercatchers on Schiermonnikoog is a single panmictic unit. Therefore, leapfrogs and residents were treated as one population for comparisons with other populations (Table 3b). None of the loci examined showed significant genetic differentiation among the four populations investigated. The overall $\Theta$-value of $-0.0006(95 \%$ CI, -0.0045-0.0037) resembled the estimate obtained for leapfrogs and residents on Schiermonnikoog, while the 95\% CI of both estimates completely overlapped. Pairwise comparison of populations revealed genetic distances ranging from 0.0028 (Schiermonnikoog-Texel) to 0.0127 
Table 1 Core sequence and size of the PCR product of eight cloned polymorphic microsatellite loci from the oystercatcher. Primer sequences and optimal annealing temperatures $\left(T_{m}\right)$ are also presented

\begin{tabular}{|c|c|c|c|c|}
\hline Locus & Core sequence & PCR product size (bp) & Primer sequences $\left(5^{\prime} \rightarrow 3^{\prime}\right)$ & $T_{m}\left({ }^{\circ} \mathrm{C}\right)$ \\
\hline $4 A 11$ & $(\mathrm{GT})_{9}(\mathrm{AT})_{3}(\mathrm{AC})(\mathrm{AT})_{4}$ & 159 & $\begin{array}{l}\mathrm{F}: \text { TCTAGCCTGAAAATCTGTCCTTG } \\
\mathrm{R}: \text { GGCACAAAGCTCACACCTCTATG }\end{array}$ & 60 \\
\hline $9 E 6$ & $(\mathrm{GTGC})_{3}(\mathrm{GT})_{10}$ & 165 & $\begin{array}{l}\mathrm{F}: \mathrm{GTCCCAGAGACCCATG} \\
\mathrm{R}: \text { GATCCGTCTGCTAGGG }\end{array}$ & 50 \\
\hline $16 D 10$ & $(\mathrm{~T})_{19}$ & 114 & $\begin{array}{l}\mathrm{F}: \text { AAAAAGGGAGGAAAAAGTCGAG } \\
\mathrm{R}: \text { TTCTCCTTGTCTACAGTACGGCTAC }\end{array}$ & 55 \\
\hline $18 F 9$ & $(\mathrm{CAA})_{4}(\mathrm{C})_{2}(\mathrm{~A})_{10}(\mathrm{GA})_{7}$ & 175 & $\begin{array}{l}\mathrm{F}: \text { TAAATACCTGATGCTGAATGGGATG } \\
\mathrm{R}: \text { TGCTCTGATGTTTCAACCTTATCTTG }\end{array}$ & 60 \\
\hline $20 \mathrm{H} 7$ & $(\mathrm{GT})_{11}$ & 143 & $\begin{array}{l}\mathrm{F}: \text { GAAGCCCTCTCAGCAACTTGG } \\
\mathrm{R}: \text { GATCCTAGGGCCATGCCTTG }\end{array}$ & 65 \\
\hline $44 B 7$ & $(\mathrm{~T})_{13}$ & 135 & $\begin{array}{l}\text { F:AATAGGGGGATATAACATTCTAGGC } \\
\text { R:GACTCTGCTTTTTATGCAACTCATC }\end{array}$ & 60 \\
\hline $49 F 6$ & $(\mathrm{GT})_{7}(\mathrm{~T})(\mathrm{G})_{13}(\mathrm{TGG})_{4}$ & 173 & $\begin{array}{l}\mathrm{F}: \text { GGGAACTATGGGGAAGGGTC } \\
\mathrm{R}: \text { AAAAGGGTTGTGAAAATCAGCC }\end{array}$ & 60 \\
\hline $54 F 2$ & $(\mathrm{GT})_{10}$ & 160 & $\begin{array}{l}\mathrm{F}: \text { AAAAGCAGAGGACAGAGGAGG } \\
\mathrm{R}: \text { ATTGCACATCAGCTCTAACCG }\end{array}$ & 65 \\
\hline
\end{tabular}

(Holwerd-Griend), while the estimate for leapfrogs-residents was 0.0040. In all of these comparisons, no significant allele frequency differences were observed. Our combined results strongly suggest that panmixis exists even across larger geographical distances in the north of The Netherlands and that gene flow among the populations examined must be substantial.

\section{Discussion}

Gene flow between populations is known to be a strong force opposing the effects of genetic drift (Allendorf 1983). The absence of genetic differentiation between leapfrogs and residents on the isle of Schiermonnikoog suggests that the observed transition rates are accompanied by sufficient gene flow to prevent genetic divergence. Recent preliminary data on recruitment of marked fledglings on Schiermonnikoog corroborate this conclusion. Currently, a number of chicks, resident by birth, have been observed to be recruited as leapfrog breeders (D. Heg, unpublished data). The reverse transition, leapfrog by birth recruited as resident, has not yet been observed. However, the total number of observations is still quite low. Even across larger geographical scales within the northern part of The Netherlands genetic differentiation was found to be absent, suggesting panmixis within this area as well. Thus far, detailed data about the range of migration of marked individuals are lacking, particularly because the probability of detection decreases with increasing geographical distance. However, the limited number of observations available suggests that dispersal of juvenile birds is quite common for oystercatchers. The combined data from field observations and genetical analyses therefore indicate that, despite a strong fidelity of adult oystercatchers to their breeding sites, substantial levels of gene flow in oystercatchers occur due to juvenile dispersal.

Only $33 \%$ of the loci investigated in this study were found to be polymorphic. Much higher levels of variability have been found for microsatellites in other bird studies conducted so far (Hanotte et al. 1994; Neumann \& Wetton 1996; Primmer et al. 1996). However, a striking feature of the oystercatcher data was the relatively low number of repeats of the microsatellite loci. It is generally assumed that the size of microsatellites is positively correlated with mutation rate and level of polymorphism (Weber 1990; Ellegren et al. 1995). The small size of the microsatellites may therefore account for the moderate level of variability observed in the oystercatcher. Because the synthetic oligonucleotides $(\mathrm{GT})_{7}$ and $(\mathrm{GA})_{7}$, used for the screening of the genomic library, are able to detect larger repeat arrays as well, it seems unlikely that the short microsatellites detected in the oystercatcher are due to methodological limitations. Moreover, the fact that the genomic library contained five identical microsatellite clones indicates a thorough screening of the genome. Therefore, it seems that only small (GT) and (GA) repeat arrays are present in the oystercatcher genome. However, for the polymorphic loci the majority of the microsatellite alleles showed intermediate frequencies, providing sufficient resolving power to detect genetic population structure. 
Table 2 Allele frequencies at eight polymorphic microsatellite loci in four populations of the oystercatcher. For the population Schiermonnikoog separate data are presented for leapfrogs and residents. Sample sizes $(n)$ are given between brackets. Alleles are denoted by the number of base pairs of their PCR product. $H_{\mathrm{O}}$ represents the observed and $H_{\mathrm{E}}$ the expected heterozygosity

\begin{tabular}{|c|c|c|c|c|c|c|}
\hline \multirow[b]{2}{*}{ Locus } & \multirow[b]{2}{*}{ Allele } & \multicolumn{2}{|l|}{ Schiermonnikoog } & \multirow[b]{2}{*}{ Holwerd $(n=48)$} & \multirow[b]{2}{*}{ Griend $(n=50)$} & \multirow[b]{2}{*}{ Texel $(n=50)$} \\
\hline & & Leapfrogs $(n=135)$ & Residents $(n=94)$ & & & \\
\hline \multirow[t]{2}{*}{$4 A 11$} & 159 & 0.904 & 0.926 & 0.885 & 0.950 & 0.910 \\
\hline & 165 & 0.096 & 0.074 & 0.115 & 0.050 & 0.090 \\
\hline$H_{\mathrm{O}}$ & & 0.163 & 0.149 & 0.229 & 0.100 & 0.140 \\
\hline$H_{\mathrm{E}}$ & & 0.175 & 0.139 & 0.205 & 0.096 & 0.165 \\
\hline \multirow[t]{3}{*}{$9 E 6$} & 165 & 0.800 & 0.835 & 0.813 & 0.730 & 0.740 \\
\hline & 167 & 0.041 & 0.027 & 0.052 & 0.100 & 0.070 \\
\hline & 169 & 0.159 & 0.138 & 0.135 & 0.170 & 0.190 \\
\hline$H_{\mathrm{O}}$ & & 0.370 & 0.330 & 0.354 & 0.500 & 0.480 \\
\hline$H_{\mathrm{E}}$ & & 0.334 & 0.284 & 0.322 & 0.433 & 0.416 \\
\hline \multirow[t]{4}{*}{$16 D 10$} & 111 & 0.011 & 0.021 & 0.031 & - & 0.030 \\
\hline & 112 & 0.678 & 0.660 & 0.646 & 0.730 & 0.660 \\
\hline & 113 & 0.307 & 0.303 & 0.281 & 0.220 & 0.290 \\
\hline & 114 & 0.004 & 0.016 & 0.042 & 0.050 & 0.020 \\
\hline$H_{\mathrm{O}}$ & & 0.422 & 0.436 & 0.625 & 0.460 & 0.460 \\
\hline$H_{\mathrm{E}}$ & & 0.448 & 0.475 & 0.506 & 0.420 & 0.484 \\
\hline \multirow[t]{3}{*}{$18 F 9$} & 175 & 0.544 & 0.590 & 0.552 & 0.610 & 0.560 \\
\hline & 179 & 0.248 & 0.234 & 0.229 & 0.190 & 0.300 \\
\hline & 180 & 0.207 & 0.176 & 0.219 & 0.200 & 0.140 \\
\hline$H_{\mathrm{O}}$ & & 0.541 & 0.628 & 0.625 & 0.540 & 0.740 \\
\hline$H_{\mathrm{E}}$ & & 0.601 & 0.569 & 0.601 & 0.557 & 0.583 \\
\hline \multirow[t]{6}{*}{$20 H 7^{*}$} & null & $-(0.159)$ & $-(0.145)$ & $-(0.136)$ & $-(0.159)$ & $-(0.177)$ \\
\hline & 141 & $0.011(0.009)$ & - & - & - & - \\
\hline & 143 & $0.537(0.452)$ & $0.553(0.473)$ & $0.625(0.540)$ & $0.690(0.580)$ & $0.610(0.502)$ \\
\hline & 145 & $0.300(0.252)$ & $0.346(0.296)$ & $0.167(0.144)$ & $0.210(0.177)$ & $0.160(0.132)$ \\
\hline & 147 & $0.007(0.006)$ & - & - & - & - \\
\hline & 149 & $0.144(0.121)$ & $0.101(0.086)$ & $0.208(0.180)$ & $0.100(0.084)$ & $0.230(0.189)$ \\
\hline$H_{\mathrm{O}}$ & & 0.348 & 0.340 & 0.333 & 0.240 & 0.280 \\
\hline$H_{\mathrm{E}}$ & & $0.603(0.426)$ & $0.567(0.415)$ & $0.544(0.406)$ & $0.475(0.336)$ & $0.555(0.376)$ \\
\hline \multirow[t]{5}{*}{$44 B 7$} & 134 & 0.222 & 0.149 & 0.125 & 0.210 & 0.140 \\
\hline & 135 & 0.078 & 0.074 & 0.094 & 0.180 & 0.050 \\
\hline & 136 & 0.026 & 0.032 & 0.063 & 0.010 & 0.050 \\
\hline & 137 & 0.285 & 0.287 & 0.313 & 0.270 & 0.280 \\
\hline & 138 & 0.389 & 0.457 & 0.406 & 0.330 & 0.480 \\
\hline$H_{\mathrm{O}}$ & & 0.696 & 0.638 & 0.729 & 0.760 & 0.620 \\
\hline$H_{\mathrm{E}}$ & & 0.714 & 0.683 & 0.716 & 0.749 & 0.673 \\
\hline \multirow[t]{4}{*}{$49 F 6$} & 169 & 0.019 & 0.027 & 0.031 & 0.030 & 0.020 \\
\hline & 173 & 0.163 & 0.223 & 0.229 & 0.160 & 0.150 \\
\hline & 174 & 0.526 & 0.521 & 0.427 & 0.610 & 0.560 \\
\hline & 175 & 0.293 & 0.229 & 0.313 & 0.200 & 0.270 \\
\hline$H_{\mathrm{O}}$ & & 0.578 & 0.628 & 0.542 & 0.580 & 0.540 \\
\hline$H_{\mathrm{E}}$ & & 0.613 & 0.629 & 0.673 & 0.567 & 0.597 \\
\hline \multirow[t]{2}{*}{$54 F 2$} & 158 & 0.096 & 0.128 & 0.146 & 0.130 & 0.090 \\
\hline & 160 & 0.904 & 0.872 & 0.854 & 0.870 & 0.910 \\
\hline$H_{\mathrm{O}}$ & & 0.178 & 0.234 & 0.292 & 0.220 & 0.180 \\
\hline$H_{\mathrm{E}}$ & & 0.175 & 0.224 & 0.252 & 0.228 & 0.165 \\
\hline \multicolumn{7}{|l|}{ Mean } \\
\hline$H_{\mathrm{O}}$ & & 0.412 & 0.423 & 0.466 & 0.425 & 0.430 \\
\hline$H_{\mathrm{E}}$ & & $0.458(0.436)$ & $0.446(0.427)$ & $0.477(0.460)$ & $0.441(0.423)$ & $0.455(0.432)$ \\
\hline
\end{tabular}

${ }^{*}$ For this locus between parentheses the allele frequencies and $H_{\mathrm{E}}$ values, assuming the presence of a null allele, are given. The frequency of the null allele was estimated from the heterozygote deficiency by $\left(H_{\mathrm{E}}-H_{\mathrm{O}}\right) /\left(1+H_{\mathrm{E}}\right)$ (Brookfield 1996; see Van Treuren 1998). 


\begin{tabular}{|c|c|c|c|c|c|c|c|c|}
\hline \multirow[b]{2}{*}{ Locus } & \multicolumn{4}{|c|}{ (A) Leapfrog-Resident } & \multicolumn{4}{|c|}{ (B) All populations } \\
\hline & $\Theta$ & $X^{2}$ & d.f. & $P$ & $\Theta$ & $X^{2}$ & d.f. & $P$ \\
\hline $4 A 11$ & 0.0007 & 1.164 & 1 & $>0.20$ & 0.0004 & 3.096 & 3 & $>0.30$ \\
\hline $9 E 6$ & -0.0028 & 0.847 & 2 & $>0.60$ & 0.0005 & 5.808 & 6 & $>0.40$ \\
\hline $16 D 10$ & -0.0056 & 0.012 & 1 & $>0.90$ & -0.0083 & 0.440 & 3 & $>0.90$ \\
\hline $18 F 9$ & -0.0003 & 1.626 & 2 & $>0.40$ & -0.0028 & 4.778 & 6 & $>0.50$ \\
\hline $44 B 7$ & -0.0010 & 2.513 & 4 & $>0.60$ & -0.0005 & 8.460 & 9 & $>0.40$ \\
\hline $49 F 6$ & 0.0036 & 4.204 & 2 & $>0.10$ & 0.0077 & 9.217 & 6 & $>0.15$ \\
\hline $54 F 2$ & 0.0105 & 2.927 & 1 & $>0.05$ & -0.0052 & 1.380 & 3 & $>0.70$ \\
\hline Overall & 0.0000 & 13.294 & 13 & $>0.40$ & -0.0006 & 33.180 & 36 & $>0.60$ \\
\hline S.D. & 0.0015 & & & & 0.0023 & & & \\
\hline
\end{tabular}

Table 3 Level of genetic differentiation $(\Theta)$ for seven polymorphic microsatellite loci of the oystercatcher. In (A) leapfrogs and residents of the Schiermonnikoog population are compared ( $n=94$ for each subpopulation) and in (B) a separate analysis is performed for the total set of four populations ( $n=48$ for each population). $\Theta$ corresponds to $F_{\mathrm{ST}}$, which represents the fraction of the total variation that can be attributed to variation between (sub)populations. Deviations from zero (no differentiation) were chi-square tested for significance

Low frequency alleles were pooled with the nearest allele size class until expected numbers exceeded five.

Genetic relationships among the oystercatcher populations were analysed by estimating Wright's F-statistics and Nei's genetic distances. These statistics are based on the assumption that the infinite allele model can be applied to mutations at the loci investigated. It has been suggested that for microsatellites the stepwise mutation model might be more appropriate (Shriver et al. 1993; Valdes et al. 1993; Goldstein et al. 1995; Slatkin 1995; Nauta \& Weissing 1996). A statistic for genetic differentiation based on the stepwise mutation model is $R_{\mathrm{ST}}$ (Slatkin 1995). $R_{\mathrm{ST}}$ values were estimated to be $0.0041(\mathrm{SD}=0.0032)$ for the comparison between leapfrogs and residents, and $0.0088(\mathrm{SD}=0.0055)$ for the total set of four populations. These estimates were slightly higher compared to the values obtained for $\Theta$ (Table 3), but still indicate that less than $1 \%$ of the total genetic variation observed can be ascribed to differences between (sub)populations.

Genetic studies of population differentiation are relatively scarce for shorebird species. Due to their high mobility, shorebirds generally exhibit low levels of genetic differentiation, unless geographically distinct populations are studied (Wenink et al. 1993, 1994; Reed et al. 1996; Haig et al. 1997). It still remains to be answered whether the absence of genetic differentiation in oystercatchers also holds for breeding populations within Europe that are more distantly separated. If this is found to be the case, gene flow by juvenile dispersal might not be the only explanation for genetic homogeneity. It has been argued for turnstones (Arenaria interpres) that the lack of genetic population structure on a worldwide scale is due to recent expansions from a bottlenecked refugial population, rather than resulting from global gene flow (Wenink et al. 1994). If oystercatchers have been severely bottlenecked in their past history, insufficient time may have elapsed to generate genetic population subdivision. This possibility is in accordance with the relatively low level of allozyme variation (D. Heg, unpublished data) and moderate level of microsatellite variation, but not with the results obtained from a minisatellite study. In addition to microsatellites, we compared nine randomly chosen leapfrogs with nine residents by multilocus DNA fingerprinting using restriction enzyme HinfI and Jeffreys probe 33.15, revealing 51 distinguishable DNA-fragments within the $2-20 \mathrm{~kb}$ range (see Kappe et al. 1995 for procedures). Mean similarity index (Lynch 1990) within the sample of leapfrogs was 0.191 $( \pm 0.135)$, for residents $0.273( \pm 0.153)$, and for the betweengroup comparison a value of $0.171( \pm 0.131)$ was found. These values fall well within the range of $0.1-0.3$ that is usually reported for nonrelatives of bird species (Lynch 1991) and therefore do not indicate a reduced level of genetic variation. Genetic comparison of individuals and more detailed recruitment data across larger geographical scales are therefore needed to solve this matter.

In conclusion, social status and breeding-site fidelity alone are not sufficient to result in genetic differentiation within and between populations of the oystercatcher in the northern part of The Netherlands. A significant level of gene flow through juvenile dispersal probably occurs to prevent genetic differentiation.

\section{Acknowledgements}

R.V.T. was supported by the graduate school Functional Ecology and D.H. by the Life Sciences Foundation (SLW805.30.164), which are both subsidised by the Netherlands Organization for Scientific Research (NWO). We are grateful to A. Brenninkmeijer, B. de Bruijn, L. Bruinzeel, B. Ens, J. Hulscher, M. Kersten, K. Koopman, K. Oosterbeek, J.P. Peet, C.J. Smit, E. Stienen, P. van Tienen and several students for their participation in catching birds and collecting blood samples. We would like to thank B. Ens, K. Lessells and F. Weissing for participating in the project. The permission of the foundation 'Natuurmonumenten' to work in their reserves is greatly acknowledged. Three anonymous reviewers made valuable remarks on an earlier version of the manuscript. 


\section{References}

Allendorf FW (1983) Isolation, gene flow, and genetic differentiation among populations. In: Genetics and Conservation: a Reference for Managing Wild Animal and Plant Populations (eds Schonewald-Cox CS, Chambers SM, MacBryde B, Thomas L), pp. 51-65. Benjamin-Cummings, London.

Brookfield JFY (1996) A simple new method for estimating null allele frequency from heterozygote deficiency. Molecular Ecology, 5, 453-455.

Dijksen AJ (1996) Vogels Op Het Gouwe Boltje: Een Volledig Overzicht Van de Avifauna Van Texel. Langeveld \& de Rooy BV, Texel.

Ellegren H, Primmer CR, Sheldon BC (1995) Microsatellite 'evolution': directionality or bias. Nature Genetics, 11, 360-362.

Ens BJ (1992) The social prisoner: causes of natural variation in reproductive success of the oystercatcher. PhD Thesis, State University, Groningen.

Ens BJ, Kersten M, Brenninkmeijer A, Hulscher J (1992) Territory quality, parental effort and reproductive success of Oystercatchers (Haematopus ostralegus). Journal of Animal Ecology, 61, 703-715.

Ens BJ, Safriel UN, Harris MP (1993) Divorce in the long-lived and monogamous oystercatcher, Haematopus ostralegus: incompatibility or choosing the better option? Animal Behaviour, 45, 1199-1217.

Ens BJ, Weissing FJ, Drent RH (1995) The despotic distribution and deferred maturity: two sides of the same coin? American Naturalist, 146, 625-650.

Goldstein DB, Linares AR, Cavalli-Sforza LL, Feldman MW (1995) An evaluation of genetic distances for use with microsatellite loci. Genetics, 139, 463-471.

Haig SM, Gratto-Trevor CL, Mullins TD, Colwell MA (1997) Population identification of western hemisphere shorebirds throughout the annual cycle. Molecular Ecology, 6, 413-427.

Haldane JBS (1954) An exact test for randomness of mating. Journal of Genetics, 52, 631-635.

Hanotte O, Zanon C, Pugh A et al. (1994) Isolation and characterization of microsatellite loci in a passerine bird: the reed bunting Emberiza schoeniclus. Molecular Ecology, 3, 529-530.

Harris MP, Safriel UN, de Brooke ML, Britton CK (1987) The pair bond and divorce among oystercatchers Haematopus ostralegus on Skokholm Island, Wales. Ibis, 129, 45-57.

Hedrick PW, Jain SK, Holden L (1978) Multilocus systems in evolution. Evolutionary Biology, 11, 101-184.

Kappe AL, Van de Zande L, Vedder EJ, Bijlsma R, Van Delden W (1995) Genetic variation in Phoca vitulina (the harbour seal) revealed by DNA fingerprinting and RAPDs. Heredity, 74, 647-653.

Lynch M (1990) The similarity index and DNA fingerprinting. Molecular Biology and Evolution, 7, 478-484.

Lynch M (1991) Analysis of population genetic structure by DNA fingerprinting. In: DNA Fingerprinting: Approaches and Applications (eds Burke T, Dolf G, Jeffreys AJ, Wolff R), pp. 113-126. Birkhäuser-Verlag, Basel.

Nauta MJ, Weissing FJ (1996) Constraints on allele size at microsatellite loci: implications for genetic differentiation. Genetics, 143, 1021-1032.

Nei M (1972) Genetic distance between populations. American Naturalist, 106, 283-292.

Nei M (1987) Molecular Evolutionary Genetics. Columbia University Press, New York.
Neumann K, Wetton JH (1996) Highly polymorphic microsatellites in the house sparrow Passer domesticus. Molecular Ecology, 5, 307-309.

Primmer CR, Mфller AP, Ellegren H (1996) New microsatellites from the pied flycatcher Ficedula hypoleuca and the swallow Hirundo rustica genomes. Hereditas, 124, 281-283.

Queller DC, Strassmann JE, Hughes CR (1993) Microsatellites and kinship. Trends in Ecology and Evolution, 8, 285-288.

Reed JM, Fleischer RC, Eberhard J, Oring LW (1996) Minisatellite DNA variability in two populations of spotted sandpipers Actitis macularia in Minnesota, USA. Wader Study Group Bulletin, 79, 115-117.

Rice WR (1989) Analyzing tables of statistical tests. Evolution, 43, 223-225.

Shriver MD, Jin L, Chakraborty R, Boerwinkle E (1993) VNTR allele frequency distributions under the stepwise mutation model: a computer simulation approach. Genetics, 134, 983-993.

Slatkin M (1995) A measure of population subdivision based on microsatellite allele frequencies. Genetics, 139, 457-462.

Triggs SJ, Williams MJ, Marshall SJ, Chambers GK (1992) Genetic structure of blue duck (Hymenolaimus malacorhynchos) populations revealed by DNA fingerprinting. Auk, $109,80-89$

Valdes AM, Slatkin M, Freimer NB (1993) Allele frequencies at microsatellite loci: the stepwise mutation model revisited. Genetics, 133, 737-749.

Van Treuren R (1998) Estimating null allele frequencies at a microsatellite locus in the oystercatcher (Haematopus ostralegus). Molecular Ecology, 7, 1413-1417.

Weber JL (1990) Informativeness of human $(d C-d A)_{n} \cdot(d G-d T)_{n}$ polymorphisms. Genomics, 7, 524-530.

Weir BS, Cockerham CC (1978) Testing hypotheses about linkage disequilibrium with multiple alleles. Genetics, 88, 633-642.

Weir BS, Cockerham CC (1984) Estimating F-statistics for the analysis of population structure. Evolution, 38, 1358-1370.

Wenink PW, Baker AJ, Tilanus MGJ (1993) Hypervariable-control-region sequences reveal global population structuring in a long-distance migrant shorebird, the dunlin (Calidris alpina). Proceedings of the National Academy of Sciences of the USA, 90, 94-98.

Wenink PW, Baker AJ, Tilanus MGJ (1994) Mitochondrial controlregion sequences in two shorebird species, the turnstone and the dunlin, and their utility in population genetic studies. Molecular Biology and Evolution, 11, 22-31.

Workman PL, Niswander JD (1970) Population studies on Southwestern Indian tribes. II. Local genetic differentiation in the Papago. American Journal of Human Genetics, 22, 24-49.

This work was conducted at the State University Groningen where R. Van Treuren was granted a postdoctoral fellowship to apply molecular techniques in ongoing ecological research in the oystercatcher. All molecular analyses were carried out at the Department of Genetics where R. Bijlsma and L. Van de Zande are staff members. J. M. Tinbergen is a staff member and D. Heg is a PhD student at the Zoological Laboratory where research in oystercatchers is directed to their reproductive behaviour. The joint research project of the two departments aims to improve the understanding of the reproductive ecology of oystercatchers by integrating molecular genetic and ecological data. 